\title{
Monteiro Lobato e o Politicamente Correto
}

\author{
João Feres Júnior \\ Leonardo Fernandes Nascimento ${ }^{2}$ \\ Zena Winona Eisenberg ${ }^{3}$ \\ ${ }^{1}$ Professor e pesquisador do Instituto de Estudos Sociais e Políticos (IESP), da Universidade \\ do Estado do Rio de Janeiro (UERJ). E-mail: jferes@iesp.uerj.br \\ ${ }^{2}$ Doutorando em Sociologia no Instituto de Estudos Sociais e Políticos (IESP), da \\ Universidade do Estado do Rio de Janeiro (UERJ). E-mail: leofn@yahoo.com.br \\ ${ }^{3}$ Professora-assistente no Departamento de Educação da Pontifícia Universidade Católica do \\ Rio de Janeiro (PUC-Rio). E-mail: zena.eisenberg@gmail.com
}

É da natureza do debate público que ele seja centrado em questões e controvérsias. É claro que em sociedades complexas, como a nossa, que dependem em grande medida dos meios de comunicação para informar a opinião pública, a escolha das questões mais candentes não é independente do poder de agendamento da grande mídia, assim como o grau de controvérsia e o clima de opiniões não se dá à revelia dos enquadramentos propugnados por ela. Contudo, para compreendermos o processo de formação de opinião e especialmente as justificativas que sustentam a tomada de decisão acerca de uma política pública, é necessário irmos além dos vieses do debate midiático e estudarmos os discursos produzidos pelo Estado e suas agências e por especialistas dotados de saberes socialmente reconhecidos.

O diagnóstico de que a condição contemporânea é marcada por uma proliferação de linguagens mais ou menos especializadas, e muitas vezes mutuamente ininteligíveis, aparece já em autores como Jean François Lyotard (1984), que identificou tal condição como o signo do advento de uma nova era, para além da modernidade, a pós-modernidade $^{1}$. O enfraquecimento do debate pós-modernista já a partir do final dos anos 1980 não transformou totalmente o diagnóstico, mas trocou o pessimismo que marcava a atitude pós-modernista por um renovado otimismo acerca da possibilidade desse estado de coisas ser me-

DADOS - Revista de Ciências Sociais, Rio de Janeiro, vol. 56, n-1, 2013, pp. 69 a 108. 
diado e resolvido pelas instituições e práticas da democracia liberal. Jürgen Habermas talvez seja o principal ator intelectual desse projeto, particularmente por resgatar o papel da esfera pública na produção da legitimidade das instituições democráticas².

Mas é em um texto menos conhecido, intitulado "Philosophy as stand-in and interpreter" (Habermas, 1990), que o autor aborda assunto que é de sumo interesse para o presente esforço, que é o papel do intelectual crítico na democracia contemporânea. Distanciando-se dos extremos representados por Kant, que pretendia dar ao filósofo o papel de arquiteto de todo o edifício do conhecimento, e por Richard Rorty, que enxerga no caráter pré-paradigmático das Ciências Sociais a razão de sua função meramente terapêutica, Habermas defende que o intelectual crítico tem a capacidade de traduzir para a linguagem comum do mundo da vida as questões de importância pública que são formuladas primeiramente na linguagem dos especialistas, permitindo que o público se informe sobre essas questões e possa assim formar opinião acerca delas. Tal formação de opinião seria, na visão do autor, elemento fundamental para a legitimação das decisões coletivas e das instituições que as produzem. Assim, Habermas confere ao intelectual crítico papel fundamental no funcionamento da democracia contemporânea, papel esse que funcionaria como um antídoto contra o pessimismo pós-moderno, que enxerga a impossibilidade do exercício da razão uma vez que ela se encontra fragmentada em uma miríade de linguagens técnicas ${ }^{3}$.

Sem esposar completamente o otimismo de Habermas acerca da democracia liberal, partilhamos aqui o sentido crítico do esforço do autor, inclusive no que ele tem de herdeiro do espírito iluminista de crença na razão como antídoto aos abusos da própria razão - espírito esse que não é estranho a autores adeptos da hermenêutica da suspeita, como Karl Marx, Sigmund Freud, Michel Foucault (1984), entre outros. Em termos mais concretos, o presente trabalho é um estudo de caso de uma controvérsia pública recente que envolveu mídia, especialistas e governo acerca do suposto racismo contido na obra de Monteiro Lobato, mais especificamente em seu livro Caçadas de Pedrinho (Lobato, 2008). No texto que segue, após um relato dos fatos que constituíram o caso, identificaremos os argumentos de justificação das posições assumidas por diferentes agentes (ou atores), dando particular atenção para a posição do Estado, representado pelo Ministério da Educação, e da grande mídia. Pretendemos mostrar que, a despeito de fazer uso aqui e ali 
da opinião de especialistas, a mídia optou por enquadrar o caso dentro da questão mais ampla do valor do politicamente correto na sociedade contemporânea, assumindo uma posição normativa e militante - posição que inclusive contribuiu para a má compreensão da questão do racismo na obra de Lobato. Em seguida, argumentamos que a posição majoritária da mídia é factualmente equivocada no que diz respeito à dinâmica moral da sociedade contemporânea e sua relação com a linguagem, além de normativamente reacionária. Passamos então a examinar a posição do governo que, apesar de mais sensível e nuançada, peca por não levar em conta aspectos fundamentais da adequação dos argumentos críticos recomendados pelos pareceres do MEC ao nível de desenvolvimento das crianças com quem o livro será trabalhado. Na conclusão resgatamos a reflexão acerca do papel do intelectual crítico apontando para a necessidade de adotarmos uma postura pragmática ao lidar com casos como esse e com a justificação de políticas públicas em geral.

A posição estatal está explicitada nos dois pareceres produzidos pela Câmara de Educação Básica do Conselho Nacional de Educação (CEB/CNE), e homologados pelo Ministro da Educação. Já no caso da mídia, nossa análise baseia-se na leitura e codificação de todos os textos sobre o assunto publicados pelos jornais e revistas de maior circulação do país: Folha de S. Paulo, O Globo, O Estado de S. Paulo, Estado de Minas, Correio Braziliense, Jornal do Brasil, Jornal do Commercio, Zero Hora, Brasil Econômico, Veja, IstoÉ e Época ${ }^{4}$.

\section{O HISTÓRICO DO CASO}

Em 30 de junho de 2010 a Câmara de Educação Básica do Conselho Nacional de Educação (CEB/CNE) acatou solicitação encaminhada pela Ouvidoria da Secretaria de Políticas de Promoção da Igualdade Racial (SEPPIR) que dizia respeito a uma denúncia feita à Ouvidoria da SEPPIR por Antônio Gomes da Costa Neto questionando a utilização, pela Secretaria de Estado da Educação do Distrito Federal, de livro que veicularia "preconceitos e estereótipos contra grupos étnico-raciais". A denúncia logo ganhou visibilidade, pois o mesmo livro, da Editora Globo, é distribuído pelo Programa Nacional de Biblioteca na Escola (PNBE) e tido há muitas décadas como obra de referência em escolas públicas e particulares de todo Brasil. Diante disso, a CEB/CNE produziu dois pareceres ${ }^{5}$ que foram objeto de grande controvérsia midiática. A denúncia tinha como objeto o clássico infantil Caçadas de Pedri- 
nho do escritor paulista Monteiro Lobato (2008) e identificava, com exemplos textuais, a presença no livro de expressões de racismo e estereotipias em relação aos negros, sobretudo nas referências à personagem Tia Nastácia. Entre as passagens do livro citadas no texto da denúncia estão:

Pedrinho pediu à boneca que repetisse a sua conversa com os besouros espiões. Emília repetiu-a, terminando assim:

-É guerra e das boas. Não vai escapar ninguém — nem Tia Nastácia, que tem carne preta. As onças estão preparando as goelas para devorar todos os bípedes do sítio, exceto os de pena (Lobato, 2008).

Sim, era o único jeito - e Tia Nastácia, esquecida dos seus numerosos reumatismos, trepou que nem uma macaca de carvão pelo mastro de São Pedro acima, com tal agilidade que parecia nunca ter feito outra coisa na vida senão trepar em mastros (Lobato, 2008).

A partir da denúncia, a CEB/CNE produziu em 1o de setembro de 2010 um primeiro parecer. Baseado em fontes como uma nota técnica produzida no âmbito da Secretaria de Educação Continuada, Alfabetização e Diversidade (SECAD/MEC); uma nota da Coordenação Geral de Material Didático do MEC; a legislação federal que regula tanto as práticas de racismo quanto a educação; diretrizes internas do MEC - que estabelecem diretrizes curriculares em âmbito nacional e critérios para a educação das relações étnico-raciais; e a opinião de especialistas, o parecer recomenda algumas medidas. Primeiramente, (a) o desenvolvimento de um programa de capacitação de professores para "lidar pedagogicamente e criticamente com o tipo de situação narrada, a saber, obras consideradas clássicas presentes na biblioteca das escolas que contêm estereótipos raciais"; (b) o cumprimento por parte da Coordenação Geral de Material Didático do MEC dos critérios por ela mesma estabelecidos na avaliação dos livros indicados para o PNBE; ou seja, que neles haja "ausência de preconceitos, estereótipos, não selecionando obras clássicas ou contemporâneas com tal teor crítico com a questão do racismo dentro das salas de aula"; e, logo em seguida, como ressalva à recomendação anterior, (c) que, "caso algumas das obras selecionadas pelos especialistas, e que componham o acervo do PNBE, ainda apresentem preconceitos e estereótipos", a editora responsável pela publicação deve ser instada pela Coordenação Geral de Material Didático e a Secretaria de Educação Básica do MEC a adicionar uma "nota explicativa e de esclarecimentos ao leitor sobre os estudos atuais e críti- 
cos que discutam a presença de estereótipos raciais na literatura". Esta última recomendação ainda explicita que a medida deve ser tomada "em relação ao livro Caçadas de Pedrinho" e estendida "a todas as obras literárias que se encontrem em situação semelhante" (Gomes, 2010:5-6).

Para o presente propósito, é necessário notar que os especialistas nomeados no primeiro parecer pertencem todos à área de estudos literários. Ademais, a maneira como a segunda e a terceira recomendações são apresentadas dão a entender que, a despeito de pedir que a Coordenação Geral de Material Didático do MEC respeite os critérios, o parecer concede que algumas obras com preconceitos e estereótipos sejam selecionadas para o PNBE, desde que contenham nota explicativa discutindo o estado da arte da crítica acerca da presença de estereótipos raciais na literatura.

No decorrer da segunda quinzena do mês de outubro de 2010, o primeiro parecer foi assunto de várias matérias jornalísticas. As matérias se referiam às duas pessoas diretamente envolvidas no caso: $\mathrm{o}$ autor da denúncia à SEPPIR, Antônio Gomes da Costa Neto, e a relatora da $\mathrm{CEB} / \mathrm{CNE}$, a professora Nilma Lino Gomes, expondo inclusive seus currículos e filiações político-partidárias. Tais matérias eram francamente contrárias ao parecer, acusando-o de censurar ou vetar a literatura e o próprio escritor Monteiro Lobato. Ainda necessitando de sanção por parte do Ministro da Educação, o primeiro parecer foi, por conta do forte clamor na mídia, devolvido para o CEB/CNE para uma nova avaliação. Dez meses depois, um segundo parecer, mais detalhado, foi produzido. Antes que um recuo por parte do MEC de sua posição primeira, tal documento parece ter sido uma tentativa de esclarecer ao público o conteúdo do parecer anterior.

O segundo parecer, de junho de 2011, é na verdade muito similar ao primeiro. O número de especialistas citados aumentou, agora incorporando dois livros de pedagogia (Cavalleiro, 2001; Rosemberg, 1985). Mas as recomendações continuaram praticamente as mesmas: (a) treinamento de professores para lidar com o assunto; (b) reiteração dos critérios para seleção de livros do PNBE; e (c) "inserção, no texto de apresentação das novas edições, de contextualização crítica do autor e da obra, a fim de informar o leitor sobre os estudos atuais e críticos que discutem a presença de estereótipos na literatura, entre eles os raciais" (Gomes, 2011:6-7). Além do desaparecimento da expressão "nota ex- 
plicativa", nota-se no texto um esforço reiterado de esclarecer que não se tratava de "veto" à obra de Monteiro Lobato.

Diante desse novo documento, os jornais retornaram ao assunto repetindo as acusações de censura em relação ao livro de Monteiro Lobato. Além disso, em colunas e editoriais, jornalistas e colaboradores passaram a desqualificar reiteradamente argumentos subjacentes ao debate tachando-os pejorativamente de "politicamente corretos". $\mathrm{O}$ assunto obteve grande visibilidade ao ponto de no carnaval do Rio de Janeiro de 2011 membros de um tradicional bloco de foliões desfilarem com camisa estampada com um desenho do cartunista Ziraldo retratando Monteiro Lobato abraçado a uma mulher negra de biquíni, acompanhados por um gato empunhando um porrete de madeira e um vaso com uma rosa ${ }^{6}$. Vide imagem abaixo:

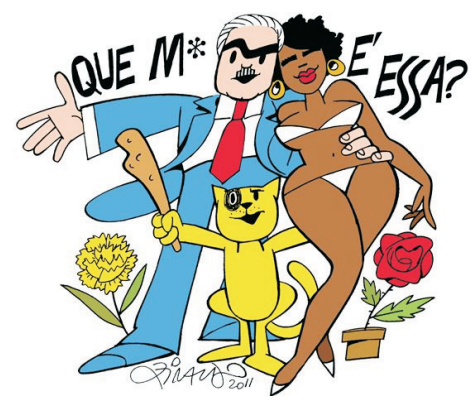

Gravura do cartunista Ziraldo

No mesmo momento do desfile do bloco, distante apenas um quarteirão da concentração, um grupo organizado protestava distribuindo uma cópia do parecer da CEB/CNE aos foliões que passavam. Além disso, foi publicada uma "Carta Aberta ao Ziraldo" 7 , através da qual a autora expõe sua indignação em relação à charge, reiterando a presença de alusões racistas na obra de Monteiro Lobato.

Por fim, em 26 de agosto de 2011, o então ministro da Educação, Fernando Haddad, homologou o segundo parecer, reiterando o argumento contido na denúncia à SEPPIR, "com orientações para que o material utilizado na Educação Básica se coadune com as políticas públicas para uma educação antirracista". Desde então, as matérias sobre o assunto se tornaram rarefeitas, persistindo apenas algumas alusões ao caso em notícias que tratam de questões semelhantes. Passemos agora à análise mais detalhada da cobertura da mídia sobre o assunto. 


\section{A MÍDIA IMPRESSA E O CASO LOBATO}

Nossa base de dados é composta de todas as matérias publicadas nos principais jornais e revistas do país que trataram ou fizeram referência aos pareceres da CEB/CNE sobre Monteiro Lobato ou, ainda, que continham alguma referência ao affair Caçadas de Pedrinho. Em seguida, fizemos uma análise do conteúdo das matérias identificando os argumentos e algumas estratégias retóricas nelas utilizados. Por fim, estabelecemos a valência (positiva, negativa ou informativa/neutra) de cada matéria. O período pesquisado foi de 1o de setembro de 2010 mês em que foi produzido o primeiro parecer - até 30 de março de 2012 - momento em que finalizamos o artigo. Obtivemos um total de 84 matérias, distribuídas percentualmente segundo o Gráfico 1 abaixo.

\section{Gráfico 1}

Quantidade de Matérias no Período por Jornal/Revista

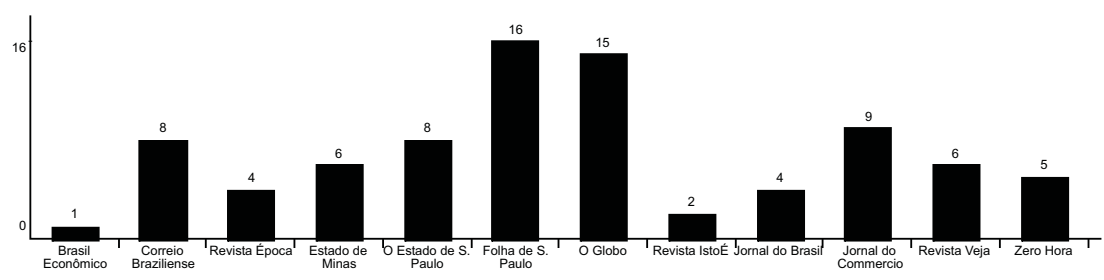

Elaboração dos autores.

Obs.: Os gráficos elaborados pelos autores baseiam-se em pesquisa realizada pelo Grupo de Estudos Multidisciplinares da Ação Afirmativa (GEMAA).

No Gráfico 2, podemos ver a frequência mensal das matérias publicadas sobre os pareceres da CEB/CNE:

\section{Gráfico 2}

Frequência Mensal de Matérias sobre os Pareceres CEB/CNE

Outubro 2010

Novembro 2010

Dezembro 2010

Janeiro 2011

Fevereiro 2011

Março 2011

Abril 2011

Maio 2011

Junho 2011

Agosto 2011

Outubro 2011

Novembro 2011

Janeiro 2012

Fevereiro 2012

Março 2012

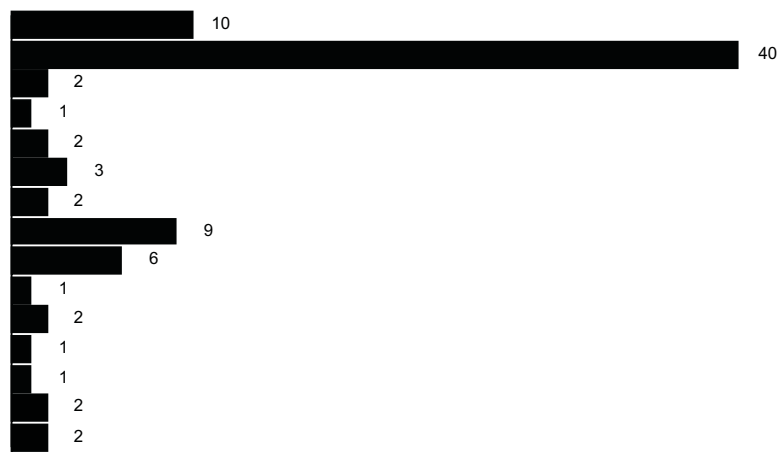

Elaboração dos autores. 
Embora o formato de uma matéria de jornal (editoriais, entrevistas, colunas, cartas de leitores etc.) esteja relacionado ao seu conteúdo, estrutura retórica (por exemplo, editoriais e cartas de leitores são abertamente opinativas, enquanto reportagens tendem a ter um tom mais descritivo e "neutro") e à sua potencial recepção por parte dos leitores (cartas de leitores são menos lidas que matérias principais), não fizemos distinção entre formatos, pois nosso objetivo aqui é apenas apresentar uma descrição geral dos principais argumentos e enquadramentos, e não uma análise a fundo do tratamento que a mídia dispensou ao caso.

Como mostra o Gráfico 3, 68\% das matérias pesquisadas sobre o assunto apresentam posições contrárias aos pareceres. Se descontarmos as matérias meramente informativas (26\%), e tomarmos somente as opinativas, vemos esta proporção aumentar para $92 \%$, enquanto meros $6 \%$ expressam opinião favorável. Importante também é notar que quase metade das matérias opinativas (42\%) abordam a questão do politicamente correto para comentar o caso. Dessas, todas menos uma são críticas ao que identificam como politicamente correto, e esta única matéria é neutra.

Mas o que seria o politicamente correto, segundo esse conjunto de matérias? Quem seriam seus agentes? Comecemos pela segunda questão. Os agentes do politicamente correto variam de texto para texto. Obviamente, o CEB/CNE, o CNE e o MEC são identificados mais frequentemente, por razões óbvias. Há também, ainda que mais raras, atribui-

\section{Gráfico 3}

Proporção de Valências acerca dos Pareceres

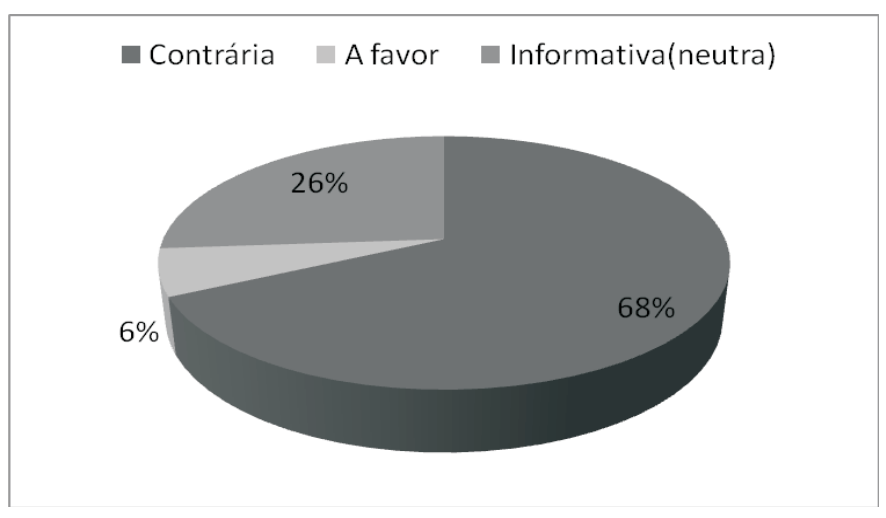

Elaboração dos autores. 
ções do politicamente correto a um Zeitgeist, o que dilui na prática a ideia de que há um agente dotado de propósito e intenções por trás dele (Martins, 29/10/2010). Por outro lado, há uma forte tendência nas matérias de atribuir a responsabilidade do politicamente correto diretamente à "linha ideológica do PT" (Editorial, 5/4/2011) e ao "governo Lula" (Fiuza, 19/3/2011), ou ao "Lulaworld" ("De olhos bem fechados", 11/11/2010), como quer um articulista. Essa tendência se identifica de maneira mais ou menos implícita também nas referências profusas à "ideologia" que pautou os pareceres do CEB/CNE - 10 matérias fazem explicitamente essa associação. É digno de nota nas passagens abaixo que portam a acusação de ideologização, o emprego de linguagem forte que beira o insulto (ênfases nossas):

O parecer que indica o perigo de incentivar preconceito e pede a retirada do livro das escolas é um exemplo de leitura viciada pela ideologia, que perde em dimensão estética e humana para bater continência ao politicamente correto. Para a Abrale, o avaliador extrapolou seu papel, caracterizando um "policiamento pedagógico e ideológico" (Werneck $e t$ alii, 30/10/2010).

Depois que Dilma Rousseff virou símbolo meteórico de afirmação feminina, ninguém mais segura os gigolôs da ideologia (Fiuza, 14/5/2011).

Reduzir um clássico da literatura a uma pinimba ideológica não é crime. Segundo os valores do Brasil de hoje, o que cada um faz ou pensa pode não ser tão importante quanto a cor da sua pele (Fiuza, 19/3/2011).

Isso é patrulha ideológica (Moreira, 28/2/2011).

Tal conexão do agente PT-governo Lula com a ideologização já é parte da resposta à primeira questão, acerca da natureza do politicamente correto. Pelo menos do ponto de vista mais externo, ele corresponderia à imposição da ideologia de um grupo de militantes de esquerda "autoritária" sobre toda a sociedade. No caso em pauta, essa imposição se faria por meio de instituições públicas de governo. O uso de palavras fortes como "patrulha" e "policiamento", nas citações acima, indica a associação do politicamente correto a métodos repressivos de cerceamento da liberdade. Reforçando a estratégia retórica de desacreditar o outro lado, o do governo, as passagens carregam no uso de expressões insultantes como "gigolôs da ideologia", "leitura viciada" e "pinimba ideológica". Mas, para ganharmos uma compreensão maior do significado em si atribuído ao politicamente correto, é necessário examinar seu emprego farto no material pesquisado (ênfases nossas): 
João Feres Júnior, Leonardo Fernandes Nascimento e Zena Winona Eisenberg

Na Constituição dos politicamente corretos - assim como nas militares -, liberdade de expressão tem limite (Fiuza, 2/4/2011).

O vírus da intolerância teve também seu lado risível no carnaval deste ano no Rio, com militantes defendendo a censura a um bloco que ousara citar em seu enredo Monteiro Lobato, por sinal outra vítima da sanha persecutória das baterias politicamente corretas (Editorial, 5/4/2011).

E aí chegamos a uma questão que me parece muito representativa dos equívocos do debate ao redor da "questão gay" (um belo exemplo do fascismo do politicamente correto) (Pondé, 30/5/2011).

O politicamente correto pode ser perigoso e hipócrita (Luft, 6/11/2010).

Ao lado do avanço nos direitos dos gays, legítimo e importante, a indústria do politicamente correto vai criando um monstro (Fiuza, 14/5/2011).

“Quem pede a suspensão de uma obra por ela conter um termo considerado discriminatório está assassinando a cultura brasileira, que a cada dia é torpedeada por novas empreitadas da patrulha do politicamente correto", diz o imortal Evanildo Bechara, membro da comissão de lexicógrafos - como são chamados os fazedores de dicionários - da Academia Brasileira de Letras (Barrucho, 3/3/2012).

Essa é mais uma amostra das "panes mentais" que a obsessão com ações politicamente corretas costuma produzir (Editorial, 5/11/2010).

Se a escola fundamental fracassa em suas tarefas elementares, como poderá incluir no currículo as disciplinas inventadas pelos luminares politicamente corretos? (Kuntz, 15/6/2011).

Trata-se de uma atitude "politicamente correta de galinheiro", como diria Nelson Rodrigues (Moreira, 28/2/2011).

O uso de linguagem pejorativa é ainda mais abundante quando as referências têm o politicamente correto como objeto explícito. Novamente associações à repressão militar e ao policiamento aparecem, mas a riqueza de termos é amplificada. O politicamente correto é ligado a um "vírus da intolerância", e suas baterias - mais uma metáfora militar dotadas de "sanha persecutória". Ele é igualado ao fascismo, chamado de perigoso e hipócrita, dito progenitor de um monstro e assassino da cultura brasileira. Associações da atitude politicamente correta com o autoritarismo e mesmo totalitarismo são feitas explicitamente em sete matérias.

Se fôssemos arriscar um argumento geral, ele teria a seguinte forma: a censura a Monteiro Lobato, produto de ações do governo capitaneado 
por radicais de esquerda avessos à liberdade, se faz em nome do politicamente correto. Outras imprecações preferem, ao invés do catastrofismo da retórica da ameaça (Hirschman, 1991), a desclassificação do politicamente correto e de seus agentes, acusando-o de produzir panes mentais, de ser operado por "luminares" - referência obviamente irônica - e de ser uma atitude de "galinheiro". Mas o sentido geral é o mesmo, como expresso nas seguintes citações lapidares (ênfases nossas):

O Estado politicamente correto sabe o que é bom para você. Em nome da modernização dos costumes, assiste-se a uma escalada medieval de proibição da propaganda de produtos que fazem mal, e de obrigatoriedade de mensagens que fazem bem (Fiuza, 14/5/2011).

Mas o extenso histórico de medidas com o viés do politicamente correto, em obediência à linha ideológica de áreas do PT e adotadas desde o primeiro governo Lula, recomenda prudência e boa dose de ceticismo em relação ao desmentido. Afinal, não é a primeira vez que o governo federal tenta empurrar goela abaixo da sociedade uma pílula supostamente progressista, que, na realidade, é um composto no qual mal se disfarça o DNA do autoritarismo e da intolerância (Editorial, 5/4/2011).

Outra característica da representação do politicamente correto nas páginas da grande mídia é sua associação aos Estados Unidos. Pelo menos cinco matérias opinativas acusam o politicamente correto de ser uma imitação dos Estados Unidos. Uma delas propugna que o CNE impõe à realidade brasileira a "visão tosca e simplista dos defensores do politicamente correto nos Estados Unidos" (Gurovitz, 6/11/2010). Um texto de autoria do deputado Aldo Rebelo - único político representado em nosso corpus - diz que o caso reproduz uma "imitação servil dos Estados Unidos, país por séculos institucionalmente racista que hoje procura maquiar sua bipolaridade étnica com ações ditas afirmativas". Segundo o autor parlamentar, trata-se de "patacoada" retórica que não serve ao Brasil, "país mestiço por excelência" (Rebelo, $7 / 11 / 2010)$. Tanto uma como outra matéria empregam linguagem pejorativa, cabe notar.

A mesma expressão "país mestiço" e o mesmo argumento são repetidos por Anna Ramalho nas páginas eletrônicas do Jornal do Brasil (Ramalho, 10/11/2010). Já Ruy Castro diz, no tocante ao caso Lobato, que "macaqueamos" aquilo que os norte-americanos têm de pior (Castro, 8/1 / 2011). Para completar, um editorial de O Globo postula que a lógica do politicamente correto é a mesma daquela por trás das cotas ra- 
ciais, as políticas de ação afirmativa: tanto o politicamente correto como as cotas raciais são importações dos EUA que não se adequam à realidade brasileira. Tal argumento acerca da ação afirmativa frequenta as matérias sobre o tema publicadas pelo jornal, que no agregado tem viés claramente contrário (Feres Júnior, 2009).

\section{LOBATO RACISTA?}

A cobertura jornalística do affair Caçadas de Pedrinho também é caracterizada por uma relativa abundância de textos, 21 no total, que contêm alguma passagem na qual o caráter racista da obra e da figura de Lobato é descontado, relativizado, quando não inteiramente descartado. Um desses textos cita o "hipotético 'racismo' de Monteiro Lobato" (Niskier, 11/2/2012). Matéria do Estado de Minas diz que aquilo que está em seu livro "não significa racismo e preconceito" (Paulo, 30/10/2010). Reportagem da Revista Época declara que "ao contrário do preconceito flagrante em Céline ou Pound, o racismo de Lobato é bastante discutível" (Masson et alii, 6/11/2010). Texto assinado por Rolf Kuntz diz que o racismo é "uma estranhíssima acusação a Monteiro Lobato" (Kuntz, 15/6/2011). Em artigo para O Globo, Martha Neiva Moreira cita o "especialista" Ricardo Cravo Albin dizendo: "- Isso é patrulha ideológica. Cresci lendo Lobato e acho injusto dizer que ele era racista" (Moreira, 28/2/2011). Mas a afirmação mais peremptória vem de comentário do escritor Ruy Castro, reproduzido por Martha Neiva Moreira na mesma matéria: "As pessoas que acusam Monteiro Lobato de racismo e de querer 'extinguir a raça negra' certamente nunca leram uma linha do que ele escreveu" (Barrucho, 3/3/2012).

Muitas vezes, a relativização ou mesmo negação do caráter racista do escritor vem acompanhada de uma apologia ao seu lugar de destaque no panteão dos heróis literários da pátria, como na passagem de Humberto Viana Guimarães:

Lobato, que além de escritor foi um grande entusiasta na criação da Petrobras, de herói, agora querem transformá-lo e a sua brilhante obra em racistas, com chavões do tipo "estereótipos raciais"... Agora é Lobato que é taxado de racista, e, amanhã quem será? Jorge Amado, Machado de Assis, Castro Alves ou Gilberto Freyre? (Guimarães, 21/11/2010)

A figura do especialista tem função fundamental na cobertura jornalística do caso. Suas opiniões, supostamente doutas, são frequentemente usadas para abonar as posições do articulista ou do texto. Quase sem 
exceção, os especialistas consultados pelos jornalistas e colunistas são literatos ou acadêmicos da área de literatura, muitos deles apresentados como experts na obra de Monteiro Lobato. Há uma abundância de referências nos textos ao fato de o parecer ter recebido críticas de especialistas, as quais são inclusive mencionadas pelo então ministro da Educação, Fernando Haddad, em entrevista (Leite, 6/11/2010; Weber, $4 / 11 / 2010)$. Quando a voz é dada nas matérias a esses especialistas, suas opiniões são consonantes com os enquadramentos do politicamente correto. Por exemplo, Marisa Lajolo, citada no Correio Braziliense como organizadora da obra de Lobato, "livro a livro", diz que "a literatura não pode vir com instrução de uso ... Essa posição é autoritária" (Leite, 6/11/2010). Vladimir Sacchetta, apresentado em matéria de $O$ Estado de S. Paulo como o "principal historiador da obra de Monteiro Lobato" e autor de uma de suas biografias, chama o parecer de "estreito e preconceituoso" (Editorial, 5/11/2010).

Segundo coluna assinada por Sérgio Augusto para O Estado de S. Paulo, o escritor João Ubaldo se refere ao parecer como "essa estupidez", "esse atraso mascarado de progresso" e condena com veemência a adoção de "certificados e bulas" nos livros aceitos na rede pública (Augusto, 6/11/2010). Outro escritor e jornalista com participação ativa no caso é Ruy Castro, cujas posições já anotamos acima em mais de uma passagem. Marcia Camargos, que matéria de O Estado de S. Paulo identifica como "especialista em Monteiro Lobato", acusa o parecer de ser "perigoso precedente rumo ao obscurantismo" (Camargos, 7/11/2010). Artigo da Folha de S. Paulo cita a mesma especialista classificando o parecer como "censura" (Paulo, 30/10/2010). O historiador da MPB, produtor musical e produtor de rádio e televisão, Ricardo Cravo Albin, rotula o parecer de "patrulha ideológica" (Moreira, 28/2/2011). Outros "especialistas" nomeados pela mídia também ecoam os mesmos enquadramentos, como o secretário-geral da Academia Mineira de Letras (AML) e a diretora de Ações de Incentivo à Leitura da Biblioteca Pública Estadual Luiz de Bessa, de Belo Horizonte. Uma fonte importante de especialistas no corpus das matérias é a Academia Brasileira de Letras, que é citada 14 vezes. A ABL publicou no dia 5 de novembro de 2011, em seu site, uma carta na qual acusa o CNE de "tentativa de censura" ao livro de Lobato.

Concluímos aqui nossa análise dos argumentos dos pareceres, do conteúdo da cobertura jornalística, na qual identificamos a proeminência do enquadramento do politicamente correto, a negação do racismo na 
obra e na figura de Lobato e a voz da autoridade conferida aos especialistas. Passamos agora à parte propositiva desse ensaio na qual mostramos, em desacordo com a opinião dominante na grande mídia, (1) o caráter inegavelmente racista da obra e do autor, (2) a necessidade fática da existência do politicamente correto em qualquer sociedade, principalmente nas sociedades democráticas contemporâneas, e sua positividade moral, e, levando em conta os dados mais sólidos acerca do desenvolvimento cognitivo e moral humano, (3) a inadequação da posição dominante na mídia e, em parte, dos pareceres do MEC, no que toca à questão do uso didático do referido livro.

\section{O RACISMO EM MONTEIRO LOBATO}

A interpretação de obras e autores do passado envolve questões de ordem epistemológica e moral. As questões de ordem epistemológica constituem o fulcro da disciplina chamada hermenêutica, desde sua fundação na Alemanha do século XIX (Rabinow e Sullivan, 1979). A hermenêutica moderna surgiu da constatação do problema de que os significados das palavras de textos antigos, originalmente a Bíblia, não correspondiam a seus significados atuais, daí a necessidade de interpretar, de "traduzir" o texto original para a linguagem do presente. Posições diferentes acerca da possibilidade do resgate dos significados do passado pelos leitores do presente foram esposadas por autores dedicados a essa disciplina ${ }^{8}$. Há, contudo, um certo consenso na literatura de que o entendimento de um conceito ou linguagem do passado requer contextualização, isto é, ele só é possível por meio do estudo dos outros conceitos, linguagens e obras que lhe foram contemporâneas, e também dos referentes no mundo aos quais aquele conceito ou linguagem se reportava (Ricoeur, 1981).

Não há espaço aqui para uma análise detalhada acerca da questão do racismo de Lobato em sua própria época, tema que mereceria um ensaio bem mais longo para ser desenvolvido 9 . Como nosso objetivo é discutir a questão relativa ao uso de sua literatura na Educação Infantil e nos anos iniciais do Ensino Fundamental no presente, é muito mais importante saber o que suas ideias e linguagem significam para nós, seres desse presente.

Veremos a seguir que há evidências suficientes para afirmar de maneira qualificada que, ao contrário da opinião de alguns especialistas retratada na mídia, Monteiro Lobato era de fato racista. De passagem, 
não podemos deixar de mencionar que Lobato foi membro da Sociedade Eugênica de São Paulo e amigo pessoal de expoentes da eugenia no Brasil, como os médicos Renato Kehl (1889-1974) e Arthur Neiva (1880-1943), dados que apenas ilustram sua imagem de adepto fervoroso dos ideais eugênicos ${ }^{10}$ de melhoramento da raça, refletidos plenamente em seus textos, privados e públicos. Vejamos um trecho de carta endereçada ao médico baiano Arthur Neiva (1880-1943):

Deversos amigos me dizem: porque não escreve suas impressões? E eu respondo: porque é inútil e seria cahir no ridículo. Escrever é apparecer no tablado de um circo muito mambembe, chamado imprensa, e exhibir-se deante de uma assistência de moleque feeble-minded e despidos da menor noção de seriedade. Mulatada, em summa. Paiz de mestiços onde o branco não tem força para organizar uma Kux-Klan, é paiz perdido para altos destinos. André Siegfried resume numa phrase as duas attitudes. "Nós defendemos o front da raça branca - diz o Sul - e é graças a nós que os Estados Unidos não se tornaram um segundo Brazil." Um dia se fará justiça ao Klux Klan; tivéssemos ahi uma defeza desta ordem, que mantem o negro no seu lugar, e estariamos hoje livres da peste da imprensa carioca - mulatinho fazendo o jogo do gallego, e sempre demolidor porque a mestiçagem do negro destróe a capacidade constructiva $^{11}$.

É muito improvável que um intelectual com vasta cultura, que havia morado nos Estados Unidos por quase quatro anos, ligado ao consulado brasileiro de Nova York, ignorasse que esse grupo racista norte-americano, apologista da pureza racial branca, praticasse linchamentos, assassinatos, incêndios criminosos e toda sorte de atrocidades contra negros daquele país. Devemos notar também que a despeito do desprezo pela miscigenação, a pureza defendida por Lobato é a da raça branca e não a da negra, tida por ele como fonte dos males da miscigenação: é a "mestiçagem do negro[que] destróe a capacidade constructiva".

Somente para exemplificar os muitos reflexos das ideias do autor em sua ficção, tomemos o livro O Presidente Negro (Lobato, 2008), publicado pela primeira vez em 1926, no qual o autor de Taubaté narra a eleição de um presidente negro nos EUA no ano de 2228. O personagem principal, um alter ego de Lobato, declara ao final do livro em caráter conclusivo, ao se concretizar o desaparecimento da raça negra por meio da esterilização de seus membros: 
Pela primeira vez na vida dos povos realizava-se uma operação cirúrgica de tamanha envergadura. $\mathrm{O}$ frio bisturi de um grupo humano fizera a ablação do futuro de um outro grupo de cento e oito milhões sem que o paciente nada percebesse. A raça branca, afeita à guerra como a última ratio da sua majestade, desviava-se da velha trilha e impunha um manso ponto final étnico ao grupo que a ajudara a criar a América, mas com o qual não mais podia viver em comum. (Lobato, 2008:196)

Mas, como dissemos, não nos ocupa agora o exame detalhado do discurso racial de Lobato em seu contexto histórico. É importante salientar, contudo, alguns pontos de sua biografia pessoal e intelectual. Lobato esposa um tipo de determinismo racial que é altamente pessimista quanto à condição do negro e do mestiço. Tal determinismo em sua época já era muito contestado, por exemplo, por figuras como o escritor Graça Aranha, o médico João Batista de Lacerda, e mesmo expoentes do Sanitarismo, como Belisário Pena, além do antropólogo Edgard Roquete Pinto, do escritor Manuel Bonfim e de Alberto Torres (Skidmore, 1976). A ideologia defendida pelo autor, a eugenia, foi o estofo do nazismo, grande causador da Segunda Guerra Mundial, da morte de mais de 20 milhões de pessoas e do genocídio de judeus, ciganos, homossexuais e outros grupos. A missiva acima, assim como muitas outras de teor similar, foi republicada em A Barca de Gleyre, livro que saiu em 1944, já nos estertores da Guerra, e organizado pelo próprio Lobato ao final de sua vida com a intenção explícita de constituir um monumento de sua própria atividade intelectual para as gerações fu$\operatorname{turas}^{12}$.

Nosso interesse aqui é pela literatura infantil de Lobato e pelo presente, ou seja, pela maneira como que esse corpus textual pode ser compreendido no presente, particularmente no tocante à questão da raça. Ainda que de maneira não tanto eugenista militante, a literatura infantil de Lobato é eivada de referências pejorativas à Tia Nastácia, e a outros personagens negros. Caçadas de Pedrinho contém os trechos supracitados, nos quais ela é chamada de "macaca de carvão", e o fato de ter "carne preta" é tomado claramente como sendo uma característica de inferioridade. Mas isso não é tudo. Em Caçadas, Lobato refere-se à Nastácia frequentemente de maneira pejorativa e desmoralizante, como, por exemplo: "resmungou a preta, pendurando o beiço"; "dizia a preta"; "tornou a preta"; "a pobre preta"; ou quando a descreve assustada, "de olhos arregalados do tamanho de xícaras de chá". 
Esse não é o único livro da série do Pica-pau Amarelo que contém tais imprecações contra Nastácia. O livro que dá início à coleção ${ }^{13}$, Reinações de Narizinho, de 1931, abre a primeira página apresentando todos os personagens. À Nastácia cabe o epíteto de "negra de estimação". Nesse livro Lobato refere-se à personagem 56 vezes usando o termo "a negra", ao invés de seu nome. Pelo menos 13 vezes tal chamamento é acompanhado de alusões pejorativas aos seus "beiços", ou às vezes "beiçaria", ao tamanho avantajado de sua boca, "a maior boca do mundo", "de caber dentro uma laranja", ou ainda a sua ignorância "tudo que ela não entendia era [para ela] inglês".

No livro Histórias de tia Nastácia, no qual é personagem principal, Nastácia, mais uma vez fartamente tratada pelo epíteto "a negra", é ofendida repetidamente por Emília, que considera suas histórias, extraídas da tradição oral, irracionais e mal articuladas. Diz a boneca: “- Essas histórias folclóricas são bastante bobas (...) Por isso é que não sou 'democrática'! Acho o povo muito idiota". Em outro trecho declara: "Tudo bobagens de negra velha... Nessa história vejo uma fieira de negras velhas, cada qual mais boba que a outra - que vão passando a história para diante, cada vez mais atrapalhada".

Mesmo Pedrinho, que inicia o livro dizendo que "as negras velhas são sempre muito sabidas", logo adota uma postura mais cética: "- Bem se vê que é história contada por negras velhas, cozinheiras" - fazendo alusão à inverosimilhança da narrativa. Logo depois Narizinho junta-se à conversa e se mostra em sintonia com a boneca na censura às histórias de Nastácia. O trecho vale a pena ser reproduzido:

— Na versão de Andersen — disse Narizinho — não há negro nenhum, nem nada de três cães. O povo aqui no Brasil misturou a velha história de Joãozinho e Maria com outra qualquer, formando uma coisa diferente. A versão de Andersen é muito mais delicada e chama-se Hansel e Gretel.

- O tal negro entrou aí - disse Pedrinho - porque no Brasil as histórias são contadas pelas negras, que gostam de enxertar personagens pretos como elas. Lá na Dinamarca Andersen nunca se lembraria de enxertar um preto porque não há pretos. Tudo gente loura.

A associação do povo brasileiro com o negro e desse com a distorção, a irracionalidade e a falta de delicadeza, como sugerido por Narizinho, se contrasta com a bela forma da história de Andersen, onde só há "gente loura". A fala de Pedrinho chega a ser cruel. Ou não? 
Lembramos que a questão que se coloca aqui é se esse tratamento dado à Nastácia e aos negros em geral na literatura infantil de Lobato pode ser tido como racista e, portanto, considerado moralmente recriminável nos dias de hoje. Para responder a essa pergunta de maneira satisfatória é necessário debruçar-nos sobre a questão central do presente artigo, que é a do politicamente correto.

\section{O QUE É O POLITICAMENTE CORRETO?}

Em passagem acima declaramos que a linguagem que Lobato usa para se referir à Nastácia é "pejorativa e desmoralizante". Em um primeiro momento, podemos afirmar que tal linguagem é desmoralizante mesmo sem necessidade de fazer uma interpretação histórica da dinâmica da mudança linguística em nossa sociedade e suas consequências políticas e institucionais - interpretação essa necessária para se discutir adequadamente a questão do politicamente correto. Parece-nos que essa distinção inicial é importante e tem um papel heurístico na consecução de nosso objetivo. Esse primeiro momento corresponderia a uma interpretação da linguagem de Lobato dentro de uma perspectiva kantiana, ou seja, assumindo somente a racionalidade do indivíduo como precondição de sua autonomia moral ${ }^{14}$. Basta uma leitura rápida pelas passagens para notar que Nastácia é retratada como racionalmente inferior, seja pela postura apatetada ou por sua ignorância profunda, faltando-lhe inclusive a virtude da coragem e da phronesis (capacidade de tomar decisões no calor da ação) - como quando acossada pelas onças (Lobato, 1933). A mesma leitura mostra claramente que sua inferioridade racional, que em termos kantianos se traduz em incapacidade moral, é associada à cor de sua pele e a características fenotípicas ancoradas na sua negritude, de maneira extremamente estereotipada. Parece-nos razoável atribuir a palavra "racismo", ainda que provisoriamente, à associação entre características fenotípicas e morais, já nesse plano.

Mas o ponto de vista kantiano, por ser radicalmente idealista, trata a linguagem como se fosse um meio transparente, em outras palavras, é incapaz de capturar o desenvolvimento moral de um povo, de uma comunidade, que se expressa na mudança linguística. Na verdade tais preocupações teóricas surgiram em grande medida no século XX, com o movimento que ficou conhecido como virada linguística. Na filosofia, a contribuição de Martin Heidegger foi fundamental para tal movimento, particularmente a noção de que a própria terminologia filosófi- 
ca se transforma com o tempo (Heidegger e Stambaugh, 1996). Com o conceito de linguisticidade (Sprachlichkeit), seu discípulo Hans Georg Gadamer coloca a linguagem como elemento inescapável da condição humana (Gadamer, 1975). Tal "tradição" angariou vários adeptos em ambos os lados do Atlântico, entre eles Richard Rorty (1967), Quentin Skinner (1969), Jacques Derrida (1976) e mesmo o Foucault do método arqueológico (1972).

A virada linguística se espalhou por outros campos de investigação, inclusive pela teoria política, que lida com assuntos mais pertinentes a nossa reflexão presente ${ }^{15}$. Se a linguagem se altera com o tempo e se a condição humana está inextricavelmente imersa nela, então as próprias noções morais que baseiam nossas instituições políticas, noções essas necessariamente expressas pela linguagem, também mudam ao longo da história. Essa hipótese, a princípio teórica, foi verificada empiricamente por um sem número de estudos, entre eles os de Norbert Elias (1982), Reinhard Koselleck $(1973,1975)$ e de grande parte da história conceitual ${ }^{16}$. Em outras palavras, as noções do que constitui bem e mal, virtude e vício e suas aplicações às coisas do mundo mudam com o passar do tempo, assim como mudam as instituições que sedimentam e estabilizam tais noções.

Para cumprir o objetivo de estudar o advento da identidade moderna, da concepção moderna de indivíduo, Charles Taylor recorre a uma reconstrução histórica das "ricas linguagens" sobre as quais "assentamos os alicerces e o sentido das obrigações morais que reconhecemos" (Taylor, 1997:16). O ponto de Taylor é que todas as concepções morais que temos, e mesmo o aspecto cognitivo das relações sociais, são expressas por meio da linguagem, a qual está em processo de constante transformação histórica. Esse processo de transformação, como indica Koselleck, não é aleatório, mas guiado pela própria dinâmica do conflito político e social em uma determinada comunidade (Koselleck, 1985). Não é possível estabelecer uma relação estrita de determinação entre história social e história semântica - do tipo infraestrutura sobre a superestrutura - mas é possível identificar, em perspectiva histórica, sua evolução conjunta (Koselleck, 1996).

Taylor resgata o conceito de reconhecimento exatamente para dar sentido a esse processo histórico de desenvolvimento moral, que é ao mesmo tempo individual e coletivo. A honra do ancien regime - estrutura de valores hierárquicos que determinavam tanto as instituições como a 
expectativa que cada um tinha acerca de suas chances de vida - foi substituída pela dignidade igual com o advento das revoluções, dignidade essa que também passou a estruturar tanto as instituições, por meio do constitucionalismo liberal, quanto as expectativas de todos de serem tratados como iguais. Mas mesmo o conteúdo dessa dignidade, o significado do que é ser igual e o rol de indivíduos que são incluídos nessa igualdade mudaram com o passar do tempo, isto é, com o transcurso da vida social e política, sempre conflituosa, geração após geração (Taylor, 1992).

A teoria do reconhecimento de Honneth (1995) avança ainda mais nesta linha de pensamento, mas concorda com todos esses elementos básicos. Para ele, a linguagem é fundamental para que o indivíduo e os grupos e movimentos sociais formem a sua identidade por meio da interação social; em outras palavras, percebam seu valor moral reconhecido por seus parceiros de interação social. Os significados portados pela linguagem são coletivamente partilhados e se transformam historicamente, isto é, o conteúdo do que é reconhecido e do que se demanda por reconhecer também evolui (Honneth, 1995). Essas transformações plasmam instituições. A série marshalliana da conquista de direitos expõe pedagogicamente esse processo: primeiro foram conquistados direitos civis, depois políticos, e depois sociais (Marshall, 1964). Hoje há quem fale de direitos de quarta e quinta ordem: culturais, reprodutivos, de gênero, raciais etc.

Como bem observa Honneth, os direitos se expandem não somente pela diferenciação, como na série acima, mas também por sua aplicação a novos grupos de pessoas antes excluídas da cidadania plena (Honneth, 1992). Por exemplo, foi somente no século XX que as mulheres conquistaram o direito de voto na maioria dos países ocidentais. Um exame rápido dos debates acerca do voto feminino mostra que a oposição a ele frequentemente se valia do argumento de que as mulheres não eram inteiramente racionais, e portanto não tinham autonomia moral para escolher um candidato (Phillips, 2003). Mutatis mutandi para os trabalhadores assalariados durante o processo de expansão do sufrágio no século XIX, e para os negros em vários países onde a escravidão foi praticada (Azevedo, 1987).

Ora, se essa interpretação linguística e histórica está correta, então somos obrigados a concluir que em um dado momento da vida de uma sociedade há um conjunto de usos e significados linguísticos que são 
aceitos pelos parceiros de interação social, os cidadãos, e outro conjunto de usos e significados proscritos, por serem considerados ofensivos, pejorativos, estereotipantes etc., seja para grupos específicos ou para o cidadão em geral. Assim, por exemplo, o termo "donzela", que antes era fartamente usado para nomear mulheres jovens, caiu em desuso por carregar a associação entre retidão moral e virgindade, algo inaceitável segundo os padrões contemporâneos dominantes de maior igualdade entre os sexos e liberalidade. $\mathrm{O}$ mesmo se deu com termos pejorativos endereçados aos negros, os quais eram usados em abundância no passado não muito remoto, mas aos poucos foram sendo proscritos das interações cotidianas e dos usos públicos da linguagem. Referências a características fenotípicas exageradas, com o intuito de marcar animalidade e falta de racionalidade, como faz Lobato; redução da pessoa à cor da pele, como na substituição de seu nome pela referência "a negra" ou "a preta"; esses são usos linguísticos não mais aceitos pelo sistema de valores democráticos de nossa sociedade. E não são aceitos porque denotam claramente a associação entre fenótipo e inferioridade moral, ou seja, por ser uma prática racista, não somente em termos kantianos abstratos, mas segundo os padrões atuais.

Mas será que há de fato um padrão atual dominante, que determina o que é aceito e o que não é? Argumentamos, contrafactualmente, que sim, caso contrário tais termos e expressões não teriam seu uso proscrito ou teriam seu significado tornado extremamente pejorativo. Há muito conflito acerca do significado de termos e conceitos em qualquer sociedade, mas esse conflito se dá por sobre uma base mais ou menos consensual do significado possível de outras palavras e também de sua aceitabilidade moral. Ou seja, nem todo o vocabulário é igualmente conflituoso, pelo contrário, o conflito se concentra em alguns conceitos-chave enquanto que outros conceitos mais decantados são tomados como plenamente inteligíveis e moralmente aceitos. Tal base existe no plano cultural. Mas a prova mais eloquente de sua existência é sua cristalização também no plano institucional.

Isso é particularmente verdadeiro para a questão do racismo no Brasil. A Constituição Federal de 1988 prevê em seu artigo 5o, inciso XLII, que a prática do racismo é crime inafiançável e imprescritível. A Lei no 7.716, de 1989, tipifica como racismo uma série de ações de privação de direitos que tenham como objeto pessoas vítimas de "preconceitos de raça ou de cor". Não bastasse tal lei, ainda foi aprovada uma lei especial, a no 9.459, de 1997, focada exclusivamente no insulto verbal racista. 
O código penal já tinha lei tipificando a injúria, mas a Lei no 9.459 faz da injúria racial um tipo qualificado do delito, impondo penas de reclusão de um a três anos e multa, se a injúria é cometida mediante "utilização de elementos referentes à raça, cor, religião ou origem".

Tal reflexão da base linguístico-moral de uma sociedade em um determinado momento histórico em suas instituições foi notada por Honneth ao argumentar que a diferenciação dos direitos é produto do rebatimento no Estado das lutas pelo reconhecimento (Honneth, 1992). Tal base linguístico-moral, que também chamamos de padrões linguísticos contemporâneos dominantes, define o "politicamente correto". Fica claro que nenhuma sociedade real existe sem uma medida do que seja o politicamente correto, isto é, da linguagem que é ou não aceita, de padrões do que é ou não ofensivo. Durante a escravidão, quando os negros sequer gozavam de direitos básicos da cidadania, o uso de linguagem derrogatória não constituía problema moral e muito menos legal. Mesmo na época em que Lobato escreveu, começo do século XX, os negros encontravam-se em tal estado de marginalidade social que poucas condições tinham de vir a público de maneira organizada criticar tais práticas. O primeiro movimento social negro de caráter nacional, a Frente Negra, surgiu somente em 1931, e já tinha como objetivo principal lutar contra o racismo e a discriminação (Moura, 1989). É natural que nos dias de hoje, após quase três décadas de normalidade democrática e de um avanço contínuo dos direitos da cidadania em nosso país, o uso de linguagem racista se torne uma questão de relevância pública, pois ele contradiz exatamente a evolução moral e institucional de nossa sociedade.

É importante fazer a ressalva de que a constatação da existência de padrões linguísticos dominantes em uma sociedade não redunda em sua positividade moral do ponto de vista do observador externo. Ainda que para o público situado em dada sociedade em um determinado momento histórico necessariamente invista tais padrões dominantes de positividade moral, pois ela é a coleção do que é correto, observadores de outras épocas ou outras sociedades podem achar tais padrões opressivos ou imorais. Por exemplo, a pederastia ateniense da época clássica era socialmente aceita, inclusive pelo pai do jovem, que aprovava a relação com o amante mais velho, mas hoje corresponderia à prática criminosa da pedofilia, mesmo que fosse aprovada pelo pai da vítima. 
Assim, os argumentos que vimos no início deste artigo contra o politicamente correto em si são equivocados do ponto de vista factual. Não há registro de sociedade histórica em que tais padrões não tenham se imposto pela força da cultura e das instituições. Os argumentos correlatos de que ele violaria o direito de livre expressão e de que seria derivado de uma posição autoritária são também espúrios. OSupremo Tribunal Federal condenou, em 17 de setembro de 2003, o editor gaúcho Siegfried Ellwanger por crime de racismo, por ter publicado material antissemita. Ora, proscrever expressões e ideologia antissemita é um exercício do politicamente correto. E a imposição do Estado, na figura do STF, não é um ato de autoritarismo, mas sim de exercício das instituições democráticas, tornando o que é moralmente condenável em interdito real. Os EUA, por exemplo, baniram do uso comum uma vasta série de termos pejorativos usados em um passado não muito remoto para designar italianos, judeus, negros, poloneses, hispano-americanos, homossexuais etc. Isso foi feito sem recurso ao autoritarismo ou atentado à liberdade de expressão. Fica claro aqui que a liberdade de expressão não pode ser tomada como um valor absoluto, que permita inclusive que crimes, como o racismo e a injúria racial, sejam praticados em seu nome. Nesse ponto a opinião não é somente nossa, mas também da Suprema Corte do Brasil.

Assim, concluímos que, para os padrões contemporâneos, a linguagem que Lobato usa em seus livros infantis para se referir à Nastácia é sim racista e que há de fato um politicamente correto, que se espelha na cultura e nas instituições, em processo histórico de constante atualização.

Mas não chegamos ainda no plano da política pública, ou seja, naquele em que poderemos concluir se seus livros devem ou não ser adquiridos pelo Estado para distribuição no sistema público de ensino fundamental. Essa é a questão principal que detonou todo o debate, ainda que ela tenha sido distorcida pela mídia, pois o fato de o parecer ter por objeto somente o programa de aquisição de livros do MEC foi esquecido e a ação da comissão do MEC foi tomada como censura estatal e atentado à livre expressão de ideais. Outra distorção fundamental cometida pelos meios de comunicação, e que diz respeito a um dos pontos do presente artigo, foi ter nomeado como especialistas para opinar sobre o assunto exclusivamente acadêmicos da área de literatura e escritores, particularmente especialistas na obra de Lobato, como se para resolver a questão bastasse determinar se Lobato era ou não racista. A maioria dos es- 
pecialistas afirmou que no passado os padrões do aceitável eram diferentes daqueles que temos no presente - argumento que de fato corrobora a existência concreta do politicamente correto. Dessa maneira, deixaram de lado a questão principal que seria avaliar se aqueles padrões passados seriam aceitáveis no presente. Mas isso não é tudo. Além de determinar se o texto de Lobato era ou não racista aos olhos do presente, o que já fizemos, é preciso saber se não há problema em usar esse texto, em sua redação original, na Educação Infantil ou nos anos iniciais do Ensino Fundamental. Mas para isso seria preciso ouvir especialistas da Educação e da Psicologia do Desenvolvimento, e não professores de literatura e escritores.

Já que a grande mídia não discutiu o assunto nessa perspectiva, que nos parece fundamental, nós o faremos.

\section{A QUESTÃO DA LINGUAGEM, DO PENSAMENTO E DO COMPORTAMENTO}

Para melhor empreendermos a tarefa proposta é preciso retornar à questão da linguagem, agora não no plano histórico e sociológico, como nas seções anteriores, mas no plano psicológico e sociológico, com o intuito de entender como a linguagem organiza o pensamento que leva a comportamentos consistentes com o mesmo.

Em A Construção do Pensamento e da Linguagem, Leo S. Vygotsky (2009[1934]) argumenta que a linguagem se origina nas interações sociais e é aos poucos internalizada na forma de significados e palavras. Neste processo, a linguagem entra em diálogo com o pensamento organizando-o em conceitos, concepções de mundo etc. Vygotsky enfatiza que a compreensão do mundo pela criança é mediada pela linguagem e pelos instrumentos que foram criados pelas gerações anteriores e atuais. Deste modo, a criança não tem acesso direto a um "mundo" puro e atemporal, mas o entende dentro dos limites e das mediações impostas pelos materiais que o constituem, da história que o formou e da linguagem que o organiza.

Paralelamente, Benjamin Lee Whorf (1956 [1939]), linguista norteamericano, examinou a questão do papel da linguagem no pensamento e no comportamento humano. Para ilustrar seu ponto, Whorf cita o exemplo de um armazém estocado com vasilhames de gasolina. Aqueles com a etiqueta "tambor de gasolina" provocam um tipo de comportamento de cuidado com o perigo de explosão, ao passo que aqueles com a etiqueta "tambor de gasolina vazio" provocarão um comporta- 
mento de descuido, já que o tambor está vazio. Este último comportamento não leva em conta o risco real que constitui um tambor de gasolina vazio, muito mais perigoso que o cheio, pois está repleto de gás do produto. Whorf explica que a palavra "vazio" conduz o ser humano ao erro, pois engana seu pensamento sugerindo um significado oposto ao do correto para o tambor. Ou seja, a linguagem engana tanto o pensamento como o comportamento daquele que lê a mensagem.

Whorf critica ainda o fato de linguistas e antropólogos analisarem outras culturas - ou línguas - de acordo com a sua. Ele se propõe a analisar a língua dos Hopi dentro de seus próprios parâmetros, isto é, associando o que a língua diz a como seus falantes pensam. Ele mostra, por exemplo, como no inglês padrão a experiência subjetiva da passagem do tempo é transformada em algo objetivo - dividido matematicamente em números. Assim o tempo passa em segundos, minutos, horas, semanas, meses e assim por diante. Para os falantes de Hopi a situação é bem outra. Números são usados de forma diferente, para denominar coisas que podem formar um grupo - não para elementos imaginários, como o tempo. Assim, não existe nessa língua a expressão "dez dias". Para os Hopi, a passagem de tempo seria expressa com relação a um episódio como "ele ficou até o décimo dia", ou seja, eles usam o ordinal, sequenciando os dias ao invés de contá-los. Para Whorf, esta diferença reflete formas distintas de conceber a experiência temporal, que no caso dos Hopi privilegia o evento no tempo, mais do que o próprio tempo.

Segundo aquela que ficou conhecida como a Hipótese Sapir-Whorf, nosso contato com o mundo se dá através dos hábitos de linguagem, estes constrangem e delineiam as possibilidades de pensamento e de comportamento para os indivíduos pertencentes àquele grupo.

Uma vez determinada a centralidade da linguagem na cognição e comportamento da criança, cabe agora focar o desenvolvimento da noção de tempo e a compreensão do tempo histórico. Mais especificamente, interessa saber como a criança passa a entender o tempo linear e cíclico que caracteriza nossa cultura. Pois é somente pela compreensão da forma como nossa sociedade organiza o tempo que a criança terá condições de compreender o racismo do passado, que podia ser abertamente expressado sem cuidado com o respeito ao outro; compreender o tempo presente e como o racismo existe nele; finalmente, compreender as diferenças entre passado e presente, tornando-se assim capaz de relati- 
vizar e colocar em perspectiva conteúdos linguísticos e práticas. Ora, o teor preconceituoso, humilhante e de desprezo que Monteiro Lobato coloca nas falas de Emília, Dona Benta ou Pedrinho só poderá ser relativizado pela criança (como deseja a recomendação feita pelo MEC) se ela tiver as noções temporais essenciais para esta tarefa.

O conceito mais óbvio que a criança precisa ter é o de tempo histórico. Ela precisa entender que passado e presente não são a mesma coisa; que as coisas que existem hoje, num outro tempo não existiram; que as pessoas têm crenças e valores morais que se alteram com o passar do tempo e que a história pode ser pensada em termos de séculos atrás, de décadas atrás ou até mesmo de anos atrás. A partir dessa premissa, partimos então para a tarefa de esmiuçar os conceitos que precedem esse tempo histórico e que alicerçam seu aprendizado.

A criança quando nasce forma representações gerais de eventos (Nelson e Gruendel, 1986) que contêm mini-sequências temporais, semelhantes aos esquemas de Piaget (2002[1946]). A partir de esquemas que se repetem, como por exemplo a amamentação, a criança extrai noções temporais do tipo sequência, duração e simultaneidade. Nelson argumenta que são essas representações gerais de eventos que geram os scripts: formas mais elaboradas de sequenciamento de eventos que duram algumas horas ou um dia inteiro. Uma criança de 2 ou 3 anos pode ter um script de uma ida ao restaurante ou do seu dia na escola. Os scripts, que se realizam através da linguagem, permitem que a criança extraia conceitos de ordem, duração e simultaneidade, assim como aprenda a linguagem que representa e organiza o tempo, como, antes, depois, enquanto, durante etc.

Nesse período da vida, a criança vive mormente no presente. Ela tem noções rudimentares de um pouco antes, um pouco depois, do aquiagora. Somente após os 3 ou 4 anos é que ela começa a expandir seu conhecimento para um passado ou um futuro mais distantes, ainda que de forma assimétrica: o passado se amplia mais rápido que o futuro, pois encontra suporte na memória. O planejamento do futuro requer levantamento de hipóteses e abstrações que estão além da capacidade cognitiva da criança pequena (Eisenberg, 2011).

Em sua descrição do desenvolvimento da inteligência, Piaget indica incapacidade da criança menor de 7 anos de reverter ações ou manipular em pensamento mais de um objeto. Assim, a irreversibilidade que caracteriza o pensamento da criança pequena impede que ela possa 
navegar num tempo histórico e voltar ao presente. Isso está intimamente ligado ao desenvolvimento de noções temporais, que, segundo apontam os estudos de Friedman (2000), é lento. A noção de calendário só se solidifica aos 9 ou 10 anos, ou seja, no 3o ao 5a ano do Ensino Fundamental. O desenvolvimento da noção de tempo histórico é ainda mais tardia, acontecendo, segundo Piaget, entre os 10 e 13 anos de idade (Piaget, 2002 [1946]). E isso em situações mais ou menos ideais de desenvolvimento.

Se tomarmos a realidade da Educação Fundamental pública em nosso país veremos um quadro certamente diferente. Por exemplo, um estudo recente mostra que crianças no 5 o ano em escolas rurais sequer sabem ler as horas fracionadas no relógio analógico (Eisenberg et alii, no prelo). Corroborando a tese de que na realidade da educação brasileira esse desenvolvimento é ainda mais tardio, Araújo (1998) conclui, em pesquisa com alunos da $5^{a}$ série (atual 6o ano) com idades entre 10 e 14 anos, da região metropolitana do Rio de Janeiro, que suas noções de tempo eram vazias de referências socio-históricas. No mesmo sentido vão os argumentos de Nadai e Bittencourt (1992/1988) que relacionam a dificuldade de ensinar história com a dificuldade da apreensão da noção de tempo. As autoras discutem a tese de que é difícil ensinar história nos anos iniciais do Ensino Fundamental e que essa disciplina só deveria entrar de fato a partir do $7^{\circ}$ ou $8^{\circ}$ anos. Para tal, compararam as

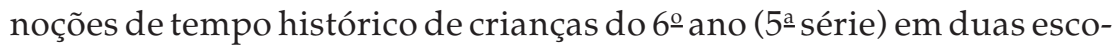
las - uma de aplicação da Universidade de São Paulo (USP) (cujas crianças tinham entre 10 e 11 anos de idade) e outra pública (cujas idades variavam entre 10 e 18 anos). Seus resultados mostram que as crianças da escola de aplicação conseguiam navegar no tempo cronológico, mas as da escola pública apresentaram maiores dificuldades. As autoras concluem que é possível pensar o tempo histórico a partir do 6 o ano do Ensino Fundamental, mas que este trabalho deve ser intencional e cuidadosamente elaborado.

Tal realidade parece não ser uma exclusividade do Brasil, pois em estudo com crianças do 4o ao 8o ano do Ensino Fundamental da Turquia, Safran e Şimşek (2006) constatam que as crianças turcas não têm noções de tempo histórico e cronológico completamente desenvolvidas e que sua compreensão de tempo cronológico está associada ao seu conhecimento de matemática e ao desenvolvimento da linguagem. 
Portanto, conclui-se que a noção de calendário e de tempo histórico, assim como outras noções mais básicas como hora no relógio, dias da semana etc., ainda não estão totalmente formadas em crianças cursando os anos iniciais do Ensino Fundamental, e o que dirá da Educação Infantil. Mas se os alunos têm, quando muito, uma compreensão deficiente de tempo histórico, como poderia um professor "problematizar" o texto de Lobato, usando-o assim para discutir uma época em que o racismo era aberto em comparação a outra, em que ele é ofensa e crime? Fica claro que a recomendação do MEC, por mais bem intencionada que seja, não resolve o problema, pois o treinamento para que professores sejam capazes de interpretar a nota explicativa e contextualizar as expressões racistas do texto é só parte da solução, a outra, o desenvolvimento necessário para tal tarefa cognitiva está fora do alcance dessa medida. Dado que a literatura infantil de Lobato é tradicionalmente usada nos quatro primeiros anos do Ensino Fundamental, então o problema é mais sério do que originalmente imaginado pelo parecer do CNE ou pela austera crítica midiática.

\section{CONCLUSÃO}

O presente artigo pretende ser uma contribuição ao estudo do espaço público, uma disciplina ainda informe nos currículos acadêmicos, mas que está aos poucos sendo consolidada a partir da interface entre teoria democrática, análise do discurso, estudos de mídia e estudo das políticas públicas ${ }^{17}$. Trata-se aqui de estudo de caso de uma controvérsia deflagrada pela grande mídia a partir de uma decisão governamental. Em tal controvérsia a mídia produziu um "espaço público" caracterizado por um forte desequilíbrio entre posições favoráveis e contrárias à decisão do governo, com larga vantagem para as contrárias. A análise do corpus composto por todas as matérias sobre o assunto publicadas nos jornais e revistas de maior circulação no país mostra a proeminência do enquadramento do assunto como decorrência da imposição do politicamente correto por parte de um governo liderado por radicais de esquerda autoritários. Ademais, a cobertura fez amplo uso da opinião de especialistas do campo da literatura para referendar tal posição crítica, chegando até em muitas instâncias a relativizar ou mesmo negar o caráter racista da obra e da figura de Lobato.

Até esse ponto nossa contribuição foi mormente analítica. Contudo, trata-se aqui de ir além e propor sínteses de caráter normativo, ainda que baseadas em firmes evidências empíricas. Assim, na segunda par- 
te do trabalho argumentamos que a questão do racismo na obra de Lobato tem que ser tomada da perspectiva do presente, isto é, devemos responder à seguinte questão: nos dias de hoje, devem as referências à Tia Nastácia contidas em Caçadas de Pedrinho e alhures ser consideradas racistas? A resposta é definitivamente afirmativa. Tal resposta é incontroversa mesmo se usarmos um critério kantiano de respeito, baseado na premissa abstrata e universal da racionalidade do sujeito. Ora, na obra do autor, Nastácia tem seu comportamento apatetado, medroso, tradicional e supersticioso, em uma palavra, irracional, associado a características fenotípicas que marcam a negritude, com requintes de exageros estereotípicos.

Mas o modelo kantiano, por ser idealista e abstrato, não descreve bem a realidade histórica da evolução moral e institucional das sociedades, que se dá em grande medida na e por meio da linguagem. Foi e é assim em nossa sociedade, e também em outros lugares do mundo, dada a condição eminentemente linguística da existência humana, as lutas e movimentos sociais sempre se dão em torno e por meio da linguagem e causam não somente sua transformação, mas também a transformação da cultura e das instituições de uma sociedade. Assim, a existência do politicamente correto é um dado da vida comunal de qualquer sociedade, principalmente nas sociedades democráticas contemporâneas. Sua positividade moral se afirma tanto no âmbito da cultura, naquilo que Habermas chamou mundo da vida, quanto nas instituições sociais; nas públicas e mesmo nas privadas. É claro que a expressão "politicamente correto" é usada, muitas vezes, com caráter derrogatório, ou seja, ela se tornou um termo de guerra da batalha ideológica. Mas isso não diminui sua propriedade como conceito analítico sociológico e político: ela descreve um fato social concreto.

O exame contrafactual da questão revela o quão distorcido é esse ataque barato ao politicamente correto. Se não houvesse padrão para o que é aceitável do ponto de vista moral e também fático, então seria praticamente impossível compor um currículo escolar, escolher livros para tal currículo, planejar aulas etc. É somente pela adoção de critérios do que é aceitável, tanto do ponto de vista moral quanto fático, que atividades como essas podem ser empreendidas pelo estado e também por instituições privadas. Se não temos critérios, então por que banir do currículo escolar temas como a pedofilia, o tratamento humilhante das mulheres, a tortura sádica de animais, sacrifícios humanos etc.? 
Assim, fica claro que temos e devemos ter critérios, e parece-nos bem razoável hoje incluirmos o racismo entre as coisas abjetas que não devem ser ensinadas a nossos filhos.

A ideia de que essa é uma controvérsia ou polêmica entre a proibição da prática do racismo, que é um crime, e o exercício da liberdade de expressão é também mal formulada. Segundo tal interpretação possível, estaríamos em face de um dilema de pesar dois valores, de um lado o combate ao racismo e de outro a liberdade de expressão, com vantagens para o segundo, pois a sociedade estaria melhor se todos pudessem abertamente expressar suas opiniões e críticas. A falácia aqui consiste em uma má compreensão do valor da liberdade de expressão. Vejamos, esse valor liberal tem como premissa a autonomia moral dos cidadãos para escolher o que bem entendem, ou melhor, o que consideram um maior bem para si mesmos e para a coletividade. Mas não há autonomia moral quando a pessoa não tem a capacidade cognitiva para entender os significados das alternativas colocadas para a escolha. É o caso nesse affair Lobato, pois, como mostramos, as crianças simplesmente não estão equipadas para estabelecer uma distância crítica entre práticas abertamente racistas do passado e sua rejeição no presente. Assim, falar de liberdade de expressão aqui já é em si uma distorção, uma falsa representação das questões envolvidas.

Restou, contudo, o argumento presente no próprio parecer do MEC de que a linguagem racista do texto de Lobato deveria ser usada como oportunidade para professores trabalharem com seus alunos a questão da discriminação racial e do racismo em nossa sociedade, colocando o linguajar de Lobato em perspectiva histórica. Para tal, o parecer inclusive sugere um programa de formação para os professores e recomenda que as editoras passem a incluir uma nota explicativa contendo avaliações críticas acerca da presença de estereótipos raciais na literatura. Infelizmente, como pretendemos ter mostrado, essa recomendação ignora o fato de que as crianças em idade de consumo da literatura infantil de Lobato, isto é, os primeiros cinco anos do Ensino Fundamental, ainda não desenvolveram a noção de tempo histórico necessária para tal compreensão, o que torna a empreitada toda, a despeito de suas boas intenções, improvável, senão impossível. Por mais bem treinados que sejam, os professores sozinhos não podem resolver o problema.

Como explicar para crianças de 6, 7,8 ou 9 anos que Monteiro Lobato, este escritor infantil magnífico, com histórias que nos levam a viajar na 
imaginação por tempos e espaços tão distantes da nossa realidade, era ao mesmo tempo extremamente racista? Que tinha desprezo pelos negros, atribuindo-lhes inferioridade moral, o que fica claro no seu tratamento da Tia Nastácia? Como relativizar o racismo para crianças cuja compreensão difere da nossa e cuja experiência e repertório são bem diferentes dos nossos? Isso nos leva à pergunta final: o que fazer com a obra de Lobato? Devemos relegá-la ao esquecimento?

A solução é na verdade simples, e já largamente praticada com a obra de outros autores clássicos. Se a escritora infantil Ruth Rocha simplifica a Odisseia para permitir que crianças possam se deleitar com suas histórias fantásticas, sem terem que se deter na cena do Livro XXII, por exemplo - quando a seta de Odisseus entra pela garganta de Antinos, pretendente de Penélope, atravessando-lhe o pescoço, e fazendo-o verter sangue abundantemente pelas narinas enquanto cai morto por sobre a mesa de repasto -, por que não permitir também que "simplifiquem" Monteiro Lobato, excluindo trechos que estão além de uma compreensão contextualizada para aquele determinado público-alvo? Há um sem número de livros e coleções infantis e infanto-juvenis em que textos de autores clássicos como Alexandre Dumas, Herman Melville, Charles Dickens, Mark Twain e o próprio Homero são adaptados para a idade desse público; então por que Monteiro Lobato seria intocável? Que preciosidade há nos seus escritos que não podem ser alterados, em nenhuma vírgula, para contribuir para o processo pedagógico e, ao mesmo tempo, evitar que esse mesmo processo sirva de meio para disseminação de preconceitos que hoje repudiamos veementemente, como esse que Lobato coloca na voz da boneca Emília?

- Mentira de Narizinho! Essa negra não é fada nenhuma, nem nunca foi branca. Nasceu preta e ainda mais preta há de morrer. (Lobato, 1946)

Com esse esforço pretendemos mostrar que a compreensão dessa questão pública, assim como de muitas outras, só é possível se adotarmos uma abordagem multidisciplinar, que leva em consideração os vários aspectos de uma política ou decisão pública e de sua implantação e, a partir deles, produz uma síntese articulada. Tal tarefa é digna do intelectual público idealizado por Habermas, sobre o qual falamos na Introdução, mas para que vozes desse tipo tornem-se de fato públicas é preciso que tenham meios de expressão, isto é, mídias. Como vimos, no caso em questão, a grande mídia operou de maneira politizada e enviesada, preocupando-se em usar o episódio para atacar o governo, tachando-o de arauto autoritário do politicamente correto e autorizando 
especialistas que nada tinham a ver com a educação básica, verdadeiro assunto que deveria estar em pauta. Assim, o espaço público foi corrompido, e a falha que havia no parecer do MEC, de também não levar em conta em detalhe aspectos da educação ligados ao desenvolvimento infantil, ficou sem ser notada. Com esse tipo de "liberdade de expressão" perdemos todos, ou quase todos.

(Recebido para publicação em setembro de 2012)

(Reapresentado em março de 2013)

(Aprovado para publicação em março de 2013)

\section{NOTAS}

1. Tal diagnóstico é um pouco exagerado visto que Kant, já no século XVIII, havia proposto uma divisão da razão em três modalidades, pura, prática e estética, e nada mais caracteristicamente moderno, pelo menos do ponto de vista da teoria moral, do que o pensamento desse autor. A proliferação de linguagens intraduzíveis mutuamente é fato de grande importância sociológica e politológica, já a questão de se isso é modernidade, pós-modernidade ou ainda algo distinto é algo muito difícil de estabelecer, em grande parte devido à natureza polissêmica e muito pouco clara do próprio conceito de "modernidade". Sobre o tópico da crítica ao conceito de modernidade ver Feres Júnior (2010).

2. Habermas opera essa "façanha" em três momentos que seguem uma sequência de crescente otimismo: The Structural Transformation of the Public Sphere (Habermas, 1989), no qual ainda partilha do pessimismo frankfurtiano frente à sociedade de massas que se desenvolveu a partir do século XIX; The Theory of Communicative Action (Habermas, 1989), no qual ainda vê o Estado e a lei como elementos de um sistema que coloniza o mundo da vida; e Between Facts and Norms (Habermas, 1996), em que finalmente Estado, direito e ação comunicativa são plenamente integrados em um regime democrático liberal estável.

3. Anthony Giddens tem uma interpretação mais pessimista do papel dos especialistas na sociedade moderna. Para ele o questionamento da autoridade tradicional trazido pela ciência corrói inclusive a legitimidade do saber científico frente ao público e a fragmentação dos discursos racionais se dá inclusive dentro de cada especialidade, pois é comum vermos experts que divergem sobre o mesmo assunto (Beck, 1997). Entretanto, Giddens não traça claramente as consequências políticas de tal situação para as instituições da democracia representativa contemporânea, como faz Habermas. Ademais, tal leitura das coisas não cancela ou contradiz o esquema proposto pelo filósofo alemão. A autoridade dos especialistas científicos pode ser mais fugidia 
do que a autoridade das fontes tradicionais de especialização, como quer Giddens, mas ela existe em nossa sociedade e de maneira pronunciada.

4. Além desse material amplo - a maioria dos trabalhos dessa natureza se restringem a dois ou três jornais - fizemos um levantamento de reportagens de TV, mas esse teve caráter mais incompleto, pois contém matérias veiculadas somente pela Rede Globo e pelo SBT. Assim, deixaremos a análise desse material para uma futura oportunidade.

5. Parecer CNE/CEB no $15 / 2010$ e no 06/2011.

6. Essas são alusões às alterações feitas nas letras de duas canções infantis muito populares, "Atirei o pau no gato" e "O cravo e a rosa". Tais alterações, feitas supostamente por obra do "politicamente correto", têm por objetivo debelar as referências ao trato violento de animais e ao machismo nas letras das respectivas canções.

7. Disponível em: http://www.idelberavelar.com/archives/2011/02/carta_aberta_ao_ziraldo_por_ana_maria_goncalves.php. Acessado em 18/4/2012.

8. Veja, por exemplo, o debate em torno da posição de Quentin Skinner no tocante à interpretação de textos de teoria política do passado (Tully, 1988).

9. Sobre o assunto ver Lajolo (1998), Azevedo et alii (1997) e Vasconcellos (1982).

10. Eugenia, palavra que em grego significa "bem nascer", é uma ideologia que tem como base o projeto do melhoramento racial da espécie ou de grupos humanos por meio de seu controle reprodutivo, manipulando características fenotípicas, genéticas e psicológicas para tal fim. Historicamente influenciada pelo evolucionismo surgido na segunda metade do século XIX, particularmente o darwinismo social, tal ideologia atingiu grande popularidade na Europa e nos Estados Unidos nas primeiras décadas do século XX, e foi também recebida no Brasil. Com o advento da Segunda Guerra Mundial, e a derrota do projeto eugenista nazista, perdeu grande parte de seu apelo. Para a história geral dessa doutrina ver Carlson (2001). Para sua recepção no Brasil, ver Stepan (1991).

11. Carta de Monteiro Lobato enviada a Arthur Neiva em 10 de abril de 1928.

12. Em seu estudo sobre o uso de categorias raciais nos censos brasileiros, Loveman argumenta, ao examinar a introdução de Oliveira Viana ao relatório de Censo de 1920, que "por volta dos anos 1920, o determinismo racial cru que informava a análise de Viana tinha perdido espaço para uma visão científica alternativa que apontavam para a doença, o analfabetismo e o abandono governamental como os principais ao progresso brasileiro" (Loveman, 2009:466). Viana foi firme defensor da tese do branqueamento por meio da miscigenação. Lobato, ainda que tenha acabado por apoiar o movimento sanitarista, fortemente influenciado pela tese do branqueamento, manteve uma concepção racial ainda mais determinista que a de Viana.

13. Na verdade livros como A Menina do Narizinho Arrebitado (1920), Fábulas de Narizinho (1921) e vários outros foram publicados anteriormente mas depois coligidos no volume Reinações de Narizinho (1932) que é apresentado de maneira a parecer o primeiro livro da série.

14. Para uma distinção clara entre teoria moral kantiana e hegeliana ver Rorty (1993). E, para a teoria moral do autor alemão, Kant (1964). Kant de fato adiciona a boa vontade como outra precondição, além da racionalidade, para se chegar à lei moral, mas isso é de se supor que Nastácia, a "boa negra", tivesse. 
João Feres Júnior, Leonardo Fernandes Nascimento e Zena Winona Eisenberg

15. Para um bom apanhado resumido do movimento ver Rorty (1984) e para um mais detalhado Rorty (1967).

16. Ver, por exemplo, os ensaios coligidos nos múltiplos volumes do Geschichtliche Grundbegriffe (Brunner et alii, 1972), entre outras obras de referência de conteúdo similar.

17. Entre outros, o livro Shaping Abortion Discourse (Feree et alii, 2004) é um bom exemplo dessa preocupação interdisciplinar. 


\section{REFERÊNCIAS BIBLIOGRÁFICAS}

ARAÚJO, Helena Maria Marques. (1998), Tempo Rei - A Noção de Tempo em Adolescentes de 10 a 14 Anos: Implicações para o Ensino de História. Dissertação de Mestrado, Departamento de Educação, PUC-Rio, Rio de Janeiro.

AUGUSTO, Sergio. (2010), "Prosa de Sábado". O Estado de S. Paulo, 6 de novembro.

AZEVEDO, Carmen Lucia de, CAMARGOS, Marcia e SACCHETTA, Vladimir. (1997), Monteiro Lobato: Furacão na Botocúndia. São Paulo, Editora Senac.

AZEVEDO, Celia Maria Marinho de. (1987), Onda Negra, Medo Branco: O Negro no Imaginário das Elites - Século XIX. Rio de Janeiro, Paz e Terra.

BARRUCHO, Luis Guilherme. (2012), "Onde Está o Verbete `Bom-Senso'?". Veja, 3 de março.

BECK, Ulrich, GIDDENS, Anthony e LASH, Scott. (1997), Modernização Reflexiva: Política, Tradição e Estética na Ordem Social Moderna. São Paulo, Editora da Universidade Estadual Paulista.

BRUNNER, Otto, CONZE, Werner e KOSELLECK, Reinhart. (1972), Geschichtliche Grundbegriffe; historisches Lexikon zur politisch-sozialen Sprache in Deutschland. Stuttgart, E. Klett.

CAMARGOS, Márcia. (2010), "Reinações da Censura". O Estado de S. Paulo, 7 de novembro.

CARLSON, Elof Axel. (2001), The Unfit: A History of a Bad Idea. Cold Spring Harbor, New York, Cold Spring Harbor Press.

CASTRO, Ruy. (2011), "Grande Huck". Folha de S. Paulo, 8 de janeiro.

CAVALLEIRO, Eliane dos Santos. (2001), Racismo e Anti-racismo na Educação: Repensando nossa Escola. São Paulo, Selo Negro Edições.

"DE OLHOS BEM FECHADOS". (2010), Jornal do Commercio, 11 de novembro.

DERRIDA, Jacques. (1976), Of Grammatology. Baltimore, Johns Hopkins University Press.

EDITORIAL. (2010), "Reedição do `Febeapá'". O Estado de S. Paulo, 5 de novembro. (2011), "Vírus da Intolerância Ameaça IBC e Ines". O Globo, 5 de abril.

EISENBERG, Zena Winona. (2011), "O Desenvolvimento de Noções Temporais através da Linguagem". Psicologia: Reflexão e Crítica, vol. 24, pp. 80-88.

EISENBERG, Zena et alii. (no prelo), "A Compreensão de Conceitos Temporais no Ensino Fundamental".

ELIAS, Norbert. (1982), The Civilizing Process. New York, Pantheon Books.

FEREE, Myra Marx et alii. (2004), Shaping Abortion Discourse: Democracy and the Public Sphere in Germany and the United States. Cambridge, Cambridge University Press.

FERES JÚNIOR, João. (2009), “Ação Afirmativa: Política Pública e Opinião”. Sinais Sociais 3 , no 8 pp. 38-77. 
João Feres Júnior, Leonardo Fernandes Nascimento e Zena Winona Eisenberg

(2010), "Introdução a uma Crítica da Modernidade como Conceito Sociológico". Mediações - Revista de Ciências Sociais, vol. 15, no 2, pp. 28-41.

FIUZA, Guilherme. (2011), "Bolsonaro e o Fuzilamento da Direita". Época, 2 de abril. (2011), "A Ditadura Cor-de-rosa". O Globo, 14 de maio. (2011), "O Negro, a Mulher e o Circo". O Globo, 19 de março.

FOUCAULT, Michel. (1972), The Archaeology of Knowledge. New York, Pantheon Books. (1984), "What is Enlightenment?", in The Foucault Reader. New York, Pantheon Books, pp. 31-50.

FRIEDMAN, William J. (2000), "The Development of Children's Knowledge of the Times of Future Events". Child Development, vol. 71, no 4, pp. 913-932.

GADAMER, Hans Georg. (1975), Truth and Method. New York, Seabury Press.

GOMES, Nilma Lino. (2010), Orientações para que a Secretaria de Educação do Distrito Federal se abstenha de utilizar material que não se coadune com as politicas públicas para uma educação antirracista. Brasília, Ministério da Educação, Conselho Nacional de Educação.

. (2011), Reexame do Parecer CNE/CEB ñ15/2010, com orientações para que material utilizado na Educação Básica se coadune com as políticas públicas para uma educação antirracista. Brasília, Ministério da Educação, Conselho Nacional de Educação.

GUIMARÃES, Humberto Viana. (2010), "... e o Index Librorum Prohibitorum". Jornal do Brasil, 21 de novembro.

GUROVITZ, Helio. (2010), "A Ditadura, Monteiro Lobato e a Liberdade". Época, 6 de novembro.

HABERMAS, Jürgen. (1989), The Structural Transformation of the Public Sphere: An Inquiry into a Category of Bourgeois Society. Cambridge, MIT Press.

(1989), The Theory of Communicative Action. Boston, Beacon Press.

(1990), Moral Consciousness and Communicative Action. Cambridge, The MIT Press.

(1996), Between Facts and Norms: Contributions to a Discourse Theory of law and Democracy. Cambridge, MIT Press.

HEIDEGGER, Martin e STAMBAUGH, Joan. (1996), Being and Time: A Translation of Sein und Zeit. Albany, NY, State University of New York Press.

HIRSCHMAN, Albert O. (1991), The Rhetoric of Reaction: Perversity, Futility, Jeopardy. Cambridge, Mass., Belknap Press of Harvard University Press.

HONNETH, Axel. (1992), "Integrity and Disrespect: Principles of a Conception of Morality Based on the Theory of Recognition". Political Theory, vol. 20, no 2, pp. 187-202.

. (1995), The Struggle for Recognition: The Moral Grammar of Social Conflicts. Cambridge, UK; Oxford; Cambridge, MA, Polity Press/Blackwell.

KANT, Immanuel. (1964), Fundamentação da Metafisica dos Costumes. São Paulo, Cia. Ed. Nacional.

KOSELLECK, Reinhart. (1973), Kritik und Krise: eine Studie z. Pathogenese d. bürgerl. Welt. [Frankfurt (Main)], Suhrkamp. 
(1975), Preussen zwischen Reform und Revolution: allg. Landrecht, Verwaltung u. soziale Bewegung von 1791 bis 1848. Stuttgart, Klett.

(1985), Futures Past: On the Semantics of Historical Time. Cambridge and London, The MIT Press.

. (1996), "A Response to Comments on the Geschichtliche Grundbegriffe", in H. Lehmann e M. Richter (orgs.), The Meaning of Historical Terms and Concepts: New Studies on Begriffgeschichte. Washington D.C., German Historical Institute, pp. 59-70.

KUNTZ, Rolf. (2011), "De Gaulle e a Escolinha". O Estado de S. Paulo, 15 de junho.

LAJOLO, Marisa. (1998), "A Figura do Negro em Monteiro Lobato". Presença Pedagógica, vol. 4, no 23, pp. 23-31.

LEITE, Larissa. (2010), "Caçadas ao Racismo e à Censura de Lobato". Correio Braziliense, 6 de novembro.

LOBATO, José Bento Monteiro. (1933), As Caçadas de Pedrinho. São Paulo, Cia. Editora Nacional.

. (1946), Obras Completas. São Paulo, Editora Brasiliense.

. (2008), Caçadas de Pedrinho. São Paulo, Editora Globo.

. (2008), O Presidente Negro. Rio de Janeiro, Editora Globo.

LOVEMAN, Mara. (2009), "The Race to Progress: Census Taking and Nation Making in Brazil (1870-1920)". Hispanic American Historical Review, vol. 89, o 3.

LUFT, Lya. (2010), "Crucificar Monteiro Lobato?". Veja, 6 de novembro.

LYOTARD, Jean François. (1984), The Postmodern Condition: A Report on Knowledge. Minneapolis, University of Minnesota Press.

MARSHALL, Thomas Humphrey. (1964), Class, Citizenship, and Social Development; Essays. Garden City, N.Y., Doubleday.

MARTINS, Milena Ribeiro. (2010), "Não Fariam Isso se Fosse Shakespeare, diz Professora". Folha de S. Paulo, 29 de outubro.

MASSON, Celso, MAIA JUNIOR, Humberto e TURRER, Rodrigo. (2010), "Este Homem Merece Ser Censurado?". Época, 6 de novembro.

MOREIRA, Martha Neiva. (2011), "Protesto Contra Enredo Fere Espírito da Folia". O Globo, 28 de fevereiro.

MOURA, Clóvis. (1989), História do Negro Brasileiro. São Paulo, Editora Ática.

NADAI, Elza e BITTENCOURT, Circe M. F. (1992), "Repensando a Noção de Tempo Histórico no Ensino", in J. Pinsky (org.), O Ensino de História e a Criação do Fato (5a ed.). São Paulo, Editora Contexto.

NELSON, Katherine e GRUENDEL, Janice. (1986), Event Knowledge: Structure and Function in Development. Hillsdale, Lawrence Erlbaum Associates.

NISKIER, Arnaldo. (2012), "Pedagonet: A Ciência do Futuro". Correio Braziliense, 11 de fevereiro.

PAULO, João. (2010), "Politicamente Equivocado". Estado de Minas, 30 de outubro. 
João Feres Júnior, Leonardo Fernandes Nascimento e Zena Winona Eisenberg

PHILLIPS, Melanie. (2003), The Ascent of Woman: A History of the Suffragette Movement. London, Little Brown.

PIAGET, Jean. (2002) [1946], A Noção de Tempo na Criança. Rio de Janeiro, Record.

PONDÉ, Luiz Felipe. (2011), "Leave the Kids Alone". Folha de S. Paulo, 30 de maio.

RABINOW, Paul e SULLIVAN, William M. (eds.), (1979), Interpretive Social Science, a Reader. Berkeley/Los Angeles, University of California Press.

RAMALHO, Anna. (2010), "As Reinações do Brasil". Jornal do Brasil, 10 de novembro.

REBELO, Aldo. (2010), "Aldo Rebelo: Monteiro Lobato no Tribunal Literário". Folha de S. Paulo, 7 de novembro.

RICOEUR, Paul. (1981), Hermeneutics and the Human Sciences. Paris, Cambridge University Press/Editions de la Maison des Sciences de L'Homme.

RORTY, Richard. (1967), The Linguistic Turn. Recent Essays in Philosophical Method. Chicago, University of Chicago Press.

(1993), "Postmodernist Bourgeois Liberalism", in T. Docherty (org.), Postmodernism: A Reader. New York, Columbia University Press, pp. 323-328.

RORTY, Richard, SCHNEEWIND, Jerome B. e SKINNER, Quentin. (1984), Philosophy in History: Essays on the Historiography of Philosophy. Cambridge/New York, Cambridge University Press.

ROSEMBERG, Fúlvia. (1985), Literatura Infantil e Ideologia. São Paulo, Global Editora.

SAFRAN, M. e ŞIMŞEK, A. (2006), "Development of Historical Time Concept in Elementary School's Students". Elementary Education Online, vol. 5, no 2, pp. 87-109.

SKIDMORE, Thomas. (1976), Preto no Branco. Raça e Nacionalidade no Pensamento Brasileiro. Rio de Janeiro, Paz e Terra.

SKINNER, Quentin. (1969), "Meaning and Understanding in the History of Ideas". History and Theory, vol. 8, no 1, pp. 3-53.

STEPAN, Nancy. (1991), "The Hour of Eugenics": Race, Gender, and Nation in Latin America. Ithaca, Cornell University Press.

TAYLOR, Charles. (1992), "The Politics of Recognition", in C. Taylor e A. Gutmann (orgs.), Multiculturalism: Examining the Politics of Recognition. Princeton, N.J., Princeton University Press, pp. xi, 112.

. (1997), As Fontes do Self: A Construção da Identidade Moderna. São Paulo, Edições Loyola.

TULLY, James (ed.), (1988), Meaning and Context: Quentin Skinner and his Critics. Cambridge, Polity.

VASCONCELLOS, Zinda Maria Carvalho de. (1982), O Universo Ideológico da Obra Infantil de Monteiro Lobato. São Paulo, Traço Editora.

VYGOTSKY, Lev S. (2009) [1934], A Construção do Pensamento e da Linguagem. São Paulo, Martins Fontes.

WEBER, Demétrio. (2010), "Haddad Não Vê Racismo em `Caçadas de Pedrinho'". O Glo$b o, 4$ de novembro. 
WERNECK, Gustavo, OLIVEIRA, Júnia e AYER, Flávia. (2010), "Professora Dá Bomba em Monteiro Lobato". Estado de Minas, 30 de outubro.

WHORF, Benjamin Lee. (1956) [1939], Language, Thought, and Reality. Selected Writings. Cambridge, Technology Press of Massachusetts Institute of Technology. 


\begin{abstract}
Monteiro Lobato and Political Correctness

An analysis of news coverage on directives from the Brazilian Ministry of Education concerning racism in the children's book Caçadas de Pedrinho (Little Pete Goes Hunting) by Monteiro Lobato (1882-1948) reveals numerous media attacks against a purported "leftwing politically correct patrol". Such media coverage also denied or glossed over the racism in Lobato's literary work and life. The current article differs from the dominant stance in the Brazilian mainstream media by exposing the blatantly racist content of various passages in Lobato's books, the need and justification for political correctness in contemporary democratic societies, and the inappropriateness of the dominant media position and the Ministry of Education's recommendations on the use of this book in classrooms.
\end{abstract}

Key words: Monteiro Lobato; political correctness; racism; children's literature; media

\title{
RÉSUMÉ \\ Monteiro Lobato et le "Politiquement Correct"
}

Une revue de la couverture journalistique concernant des avis du Ministère de l'Éducation et de la Culture au Brésil qui dénoncent la présence de racisme chez Monteiro Lobato, auteur de l'ouvrage Caçadas de Pedrinho, révèle des attaques nourries contre une supposée "mise sous contrôle politiquement correcte issue de la gauche". Une telle couverture est aussi marquée par la négation ou la relativisation du racisme dans l'œuvre et dans la biographie de Lobato. En désaccord avec l'avis dominant chez les médias, on présente dans cet article le caractère indéniablement raciste, pour le lecteur contemporain, de plusieurs passages de l'œuvre en question; le besoin de "politiquement correct" et donc de la positivité morale dans les sociétés démocratiques contemporaines et, compte tenu du développement cognitif et moral de l'homme, l'inadéquation de la position dominante chez les médias et les rapports du MEC en ce qui concerne l'utilisation didactique de ce livre.

Mots-clés: Monteiro Lobato; "politiquement correct"; racisme; littérature pour enfants; médias 